\title{
Measuring Customer Based Brand Equity: A Case of Heineken from the Beer Market in Vietnam
}

\author{
Tran Trung Vinh ${ }^{1}$ \\ ${ }^{1}$ University of Economics, The University of Danang, Danang City, Vietnam \\ Correspondence: Tran Trung Vinh, University of Economics, The University of Danang, Danang City, Vietnam. \\ E-mail: trantrungvinh9@gmail.com
}

Received: December 6, 2016

Accepted: December 17, 2016

Online Published: February 21, 2017

doi:10.5539/ass.v13n3p177

URL: https://doi.org/10.5539/ass.v13n3p177

\begin{abstract}
This study aims at examining the practicality of a customer-based brand equity model with a case of Heineken in the Vietnamese beer market. Based on a sample of 322 consumers by using a structured questionnaire, structural equation modeling (SEM) is applied to test hypotheses. The result reveals that perceived quality, brand awareness, brand association and brand loyalty have positive and direct effects on overall brand equity. These findings have implications for marketers.
\end{abstract}

Keywords: brand equity, Heineken, beer market, Vietnam

\section{Introduction}

In recent years, with a young population structure and increasing middle class as well as the beer drinking habits of Vietnamese people, Vietnam has become a nation which has the highest beer consumption in Southeast Asia, ranking third in Asia after Japan, China and being in the top 25 of the world (Phương, 2016). As reported by the Association of Beer - Alcohol - Beverage Vietnam (VBA), Vietnam beer market has consumed about 3.4 billion liters of beer in 2015 (increased by $10 \%$ and $41 \%$ compared to those in 2014 and 2010 respectively), and this figure will be approximately 4.4 billion liters in 2016 (Nhung, 2016). However, according to many forecasts, the Vietnamese beer market will be in saturation next years and will stabilize at around 5 billion liters per year (Huong, 2016). Moreover, the competition between brands in Vietnam beer market is forecasted to be increasingly fierce. At present, apart from domestic brands, almost the internationally renowned beer brands have had increasingly strong penetration into Vietnam market such as Tiger Beer, Biere Larue, Heineken, Sapporo, Budweiser, Carlsberg, etc. Among these brands, Heineken, with the reputation of product quality, the massive covering of distribution system, the impression of communication messages and especially with the renowned brand has always been loved and has occupied a critical position in Vietnamese consumers' mind. Therefore, a brand, especially how components of brand equity of Heineken in the Vietnam beer market, has affected the buying of Vietnamese consumers, and then contributed to making Vietnam market the third largest market of Heineken, only following Mexico and Nigeria. This is what the research sets out to study.

\section{Literature Review}

\subsection{Brand Equity and Brand Equity Dimensions}

Both practitioners and academics regard brand equity as an important concept of marketing (Buil et al., 2013a). Although brand equity has been discussed from a variety of views by different researchers, it can be classified into two main perspectives: financial and customer perspectives (Keller, 1993; Chaudhuri, 1995; Chang et al., 2008). From the financial perspective, brand equity can be viewed as the financial asset value created for the business by brands (Lassar et al., 1995; Chang \& Liu, 2009); as the total value of the brand that is a separable asset when it is sold or included in a balance sheet (Feldwick, 1996). This perspective aims at estimating the value of the brand more precisely for accounting purposes or for merger, acquisitions or divestiture purposes (Mohan \& Sequeira, 2012). From a customer's perspective (customer-based brand equity), brand equity is defined as "as a set of brand assets and liabilities linked to a brand, its name and symbol that add to or subtract from the value provided by a product or service to a firm and/or to that firm's customers" (Aaker, 1991); "the differential effect of brand knowledge on consumer response to the marketing of the brand" (Keller, 1993, p. 2); "the difference in consumer choice between the focal branded product and an unbranded product given the same 
level of product features" (Yoo et al., 2000, p. 196). Customer's perspective focuses on customer's mindset. Between two main perspectives as mentioned, most studies tackled brand equity form the customer view. If a brand has no value for the customer, financial value would be zero because it does not really exist in the market place (Mostafa, 2015). Therefore, this study focuses on the customer-based brand equity.

Regarding brand equity dimensions, there are numerous different models in the literature to explain the formation of brand equity. Aaker (1991) explained brand equity measurement into four main dimensions: brand awareness, brand associations, perceived quality, and brand loyalty. Keller (1993) focused on brand awareness (recall and recognition) and brand image (a combination of favorability, strength, and uniqueness of brand associations) as two main components. Lassar et al. (1995) separated it into five components, including performance, social image, value, trustworthiness, and attachment. Berry (2000) grouped it into two classes: brand awareness and brand meaning. Similarly, later other researchers also have presented their dimensions of brand equity. However, these dimensions are quite similar and less or more inherited to one that was proposed by Aaker (1991). Moreover, many empirical researches on the dimensions of brand equity (e.g. Yoo et al., 2000; Pappu et al., 2005; Tong \& Hawley, 2009; Jalilvand et al., 2011; Buil et al., 2013b; Ahmad \& Sherwani, 2015) are all derived or adapted from Aaker (1991) model where brand equity can be measured by four constructs as mentioned. Aaker's model is one of the most cited and applied in several previous research papers (Tong \& Hawley, 2009). Therefore, dimensional model constructed by Aaker (1991) will be chosen in this study.

\subsection{The Relationships between Brand Equity and Its Dimensions}

\subsubsection{Effect of Perceived Quality on Brand Equity}

Perceived quality is defined as "customer's perception of the overall quality or superiority of a product or service with respect to its intended purpose relative to alternatives" (Aaker, 1991, p. 85). Therefore, perceived quality is a quality coming from a perception of consumer. It is not the actual quality of the product that is based on product or manufacturing orientation (Garvin, 1983). According to Farquhar (1989), brand equity will depend on perceived quality since it is necessary to develop a positive assessment of the brand in customers' memories. Hence, perceived quality is a key dimension of brand equity. Perceived quality brings value to a brand in several ways: high perceived quality would influence consumer's choice, could support a premium price, and might lead to greater differentiation and superiority of the brand which can create a greater profit margin and lead to an increase in brand equity (Yoo et al., 2000). The effect of perceived quality on brand equity was confirmed by many results from previous studies (e.g. Yoo et al., 2000; Buil et al., 2013b; Saydan, 2013; Ahmad \& Sherwani, 2015; Azadi et al., 2015). Hence, the following hypothesis of the relationship between perceived quality and brand equity is proposed:

\section{H1: Perceived quality has a significant positive direct effect on brand equity.}

\subsubsection{Effect of Brand Awareness on Brand Equity}

Brand awareness is defined as "the ability of the potential buyer to recognize and recall that a brand is a member of a certain product category" (Aaker, 1991, p. 61). It is considered to be an important construct of brand equity. Brand awareness may take two forms: recall and recognition (Rossiter \& Percy, 1997). Brands recall means when consumers see a product category, they can recall a brand name correctly, while brand recognition implies consumers have the ability to recognize a brand when they get some cues (Chi et al., 2009). Brand awareness is believed to contain the meanings of the brand. It is the first step to creating brand equity, and brand equity occurs when the consumer has a high level of awareness and familiarity with the brand (Jalilvand et al., 2011). Moreover, brand awareness can be a sign of quality and commitment, and help customers consider the brand at purchase situations (Aaker, 1991). Furthermore, a product with a high level of brand awareness can receive higher consumer preferences (Chi et al., 2009). In addition, many empirical evidences from researches (e.g. Taleghani \& Almasi, 2011; Mohan \& Sequeira, 2012; Ahmad \& Sherwani, 2015; Mostafa, 2015) supported the positive relationships between brand awareness and brand equity. Thus, the following hypothesis is formulated:

\section{H2: Brand awareness has a significant positive direct effect on brand equity.}

\subsubsection{Effect of Brand Association on Brand Equity}

Brand association is defined as "anything linked in memory to a brand" (Aaker, 1991, p. 109). A brand association is the most accepted dimension of brand equity. Chen (2001) divided brand associations into two types, including product associations and organizational associations. According to Keller (1998), brand association can be generated through the association with attitudes, attributes, and benefits respectively. Brand associations may create value for the firm and its customers by differencing and positioning the brand because it can reflect product's characteristics (Jalilvand et al., 2011), and can encourage potential customers who are 
looking for products that have the physical feature or emotional associations (Kurniawan \& Diryana, 2015). Therefore, brand equity can be strongly supported by the associations that consumer s make with a brand, which contributes to a specific brand image (Yasin et al., 2012). In other words, high brand equity means that customers have strong positive associations to the brand. Furthermore, results from various studies (e.g. Tong \& Hawley, 2009; Mohan \& Sequeira, 2012; Ahmad \& Sherwani, 2015) pointed out that brand association affects overall brand equity. Hence, the following hypothesis of the relationship between perceived quality and brand equity is suggested:

\section{H3: Brand association has a significant positive direct effect on brand equity.}

\subsubsection{Effect of Brand Loyalty on Brand Equity}

Brand loyalty is defined as "the attachment that a customer has to a brand" (Aaker, 1991, p. 39). Brand loyalty is considered as the most essential component of brand equity. Brand loyalty involves behavioral loyalty and attitudinal loyalty (Chi et al., 2009). From a behavioral perspective, brand loyalty means the frequency of repeat purchase or relative volume of same brand purchase (Tellis, 1988). From an attitudinal perspective, focus of this study, brand loyalty focuses on the tendency to be loyal to a focal brand, which is demonstrated by the intention to buy the brand as a primary choice (Yoo \& Donthu, 2001). According to Aaker (1991), brand loyalty adds value to a brand because it provides a set of habitual buyers for a long period. Moreover, brand loyalty has the power that can affect customer decision to purchase the same product or brand and decline to shift to other brands (Yoo et al., 2000). Loyal consumers show more favorable responses to a brand and are less likely to switch to a competitor just because of price (Bowen \& Shoemaker, 1998). Therefore, brand loyalty will strongly add to increasing brand equity. Many results from various studies (e.g. Yoo et al., 2000; Tong \& Hawley, 2009; Yasin et al., 2012; Buil et al., 2013b; Saydan, 2013; Ahmad \& Sherwani, 2015; Azadi et al., 2015) pointed out that brand loyalty could affect overall brand equity. Thus, the following hypothesis is formulated:

\section{H4: Brand loyalty has a significant positive direct effect on brand equity.}

\subsection{Conceptual Framework and Research Hypotheses}

Based on relationships between brand equity components and overall brand equity, a conceptual framework and hypotheses are illustrated in Figure 1.

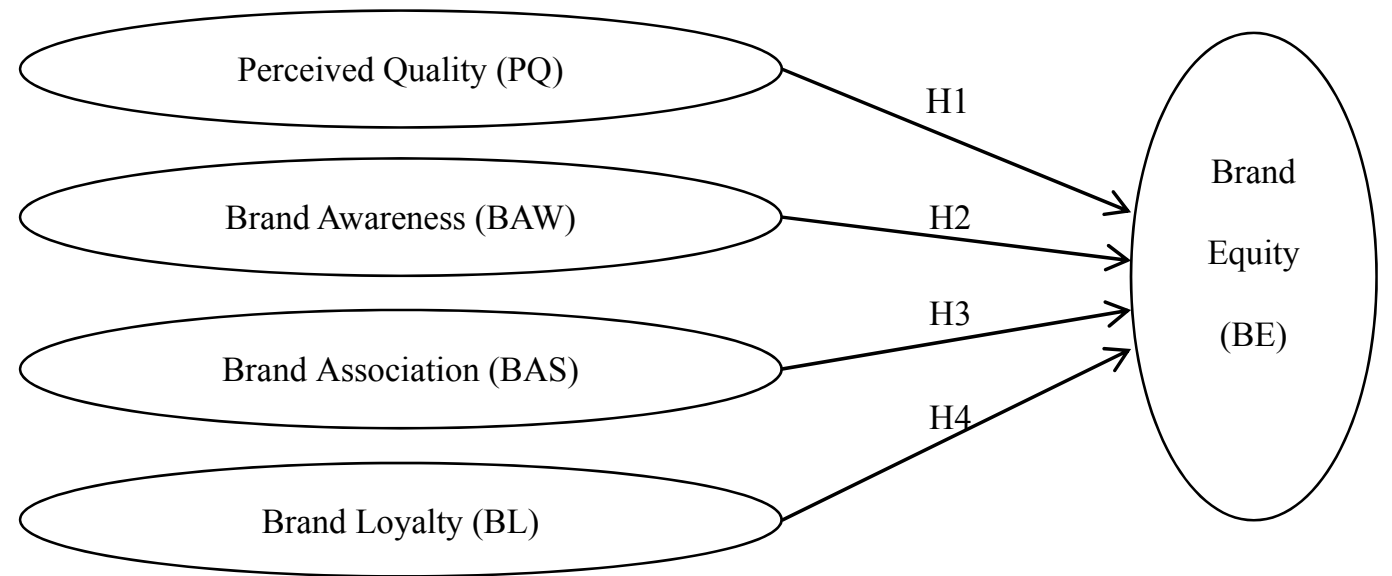

Figure 1. Conceptual framework

\section{Methodology}

\subsection{Sample Selection and Data Collection}

The empirical data in this research consists of questionnaire responses from consumers who have consumed Heineken beer in Vietnam. The survey was carried from August 2016 to October 2016. The questionnaire was firstly written in English and then translated into Vietnamese. Of the 327 received questionnaires, 322 valid questionnaires were completed, and the data from these 322 were analyzed. As such, $31.4 \%$ of respondents are younger than 25 years old; $46.3 \%$ are 25 to 45 years old and $22.3 \%$ are older than 45 years old. Males and females represent $70.8 \%$ and $29.2 \%$ of respondents respectively. Regarding income per year, it was found that $24.5 \%$ are below $\$ 2,200 ; 42.5 \%$ are $\$ 2,200$ to $\$ 8,100$ and $32.9 \%$ are higher than $\$ 8,100$. Among the 322 respondents, $57.1 \%$ live in the South (from Danang City) and the remainders live in the North (from Hue City). 


\subsection{Measurement Model}

The measures for several constructs in the framework were derived from previous studies. All items were assessed on a five-point Likert scale where 1 stands for "strongly disagree" and 5 for "strongly agree".

This research used three-item, three-item, four-item and three-item scales adapted from Tong \& Hawley (2009) measured perceived quality, brand awareness, brand association and brand equity respectively. Similarly, three items were designed to measure brand loyalty were adapted from Yoo et al. (2000).

Data analysis follows three steps. Firstly, Cronbach's alpha analysis to measure reliability coefficient for the items of each construct. Secondly, exploratory factor analysis (EFA) to determine the appropriate number of factors will be utilized in the analysis. Thirdly, confirmatory factor analysis (CFA) tests the adequacy of the measurement models. Finally, structural equation modeling (SEM) is applied to test hypotheses about theoretical relationships between latent constructs.

\section{Research Analysis and Result}

\subsection{Cronbach's Alpha Analysis}

The study used Cronbach's Alpha to measure the internal reliability of constructs. The results show that Cronbach's Alpha of perceived quality was 0.792 , brand awareness was 0.749 , brand association was 0.814 , brand loyalty was 0.893 , and band equity was 0.868 . Moreover, the item-to-total correlations were all higher the threshold of 0.30 for each component. As the alpha values for all constructs were higher than 0.7 (Nunnally \& Burnstein, 1994), it means that all scales were considered reliable.

\subsection{Exploratory Factor Analysis}

The proposed model consists of four dimensions of brand equity (brand awareness, perceived quality, brand association, brand loyalty) and overall brand equity, which are measured by 16 items. The study used a principal component analysis with varimax rotation to extract main factors. The value of Kaiser-Meyer-Olkin statistics was 0.866 , which higher than the acceptable limit of 0.5 and Bartlett's test was significant, indicating the sample size is big enough to conduct factor analysis. The result showed that five factors were produced with Eigen-value is 1.048 (> 1) contributing $73.839 \%$ to item variance. Moreover, all the indicators of each factor were significant with factor loadings higher than 0.5 (Table 1).

Table 1 . Convergent validity of the measurement model

\begin{tabular}{|c|c|c|c|c|c|c|c|c|}
\hline & \multicolumn{5}{|c|}{ Component } & \multirow{2}{*}{$\alpha$} & \multirow{2}{*}{$\mathbf{C R}$} & \multirow{2}{*}{ AVE } \\
\hline & 1 & 2 & 3 & 4 & 5 & & & \\
\hline PQ1 & & & & & 0.856 & & & \\
\hline PQ2 & & & & & 0.854 & 0.792 & 0.797 & 0.567 \\
\hline PQ3 & & & & & 0.635 & & & \\
\hline BAW1 & & & & 0.746 & & & & \\
\hline BAW2 & & & & 0.829 & & 0.749 & 0.751 & 0.501 \\
\hline BAW3 & & & & 0.806 & & & & \\
\hline BAS1 & & 0.785 & & & & & & \\
\hline BAS2 & & 0.701 & & & & 0814 & 0815 & 0525 \\
\hline BAS3 & & 0.798 & & & & 0.014 & 0.010 & 0.023 \\
\hline BAS4 & & 0.738 & & & & & & \\
\hline BL1 & 0.848 & & & & & & & \\
\hline BL2 & 0.852 & & & & & 0.893 & 0.894 & 0.737 \\
\hline BL3 & 0.879 & & & & & & & \\
\hline BE1 & & & 0.805 & . & & & & \\
\hline BE2 & & & 0.775 & & & 0.868 & 0.868 & 0,688 \\
\hline BE3 & & & 0.824 & & & & & \\
\hline Eigen value & 5.891 & 1.892 & 1.505 & 1.477 & 1.048 & & & \\
\hline Total variance explained & 36.820 & 48.647 & 58.055 & 67.289 & 73.839 & & & \\
\hline
\end{tabular}




\subsection{Confirmatory Factor Analysis}

Assessment of the measurement model was conducted using confirmatory factor analysis. As a result, all factor loadings are above 0.5 and are statistically significant. All the composite reliability (CR) coefficients varied from 0.751 to 0.894 and were above the threshold 0.70 criteria (Hair et al., 2009), indicating support for the construct reliability. Similarly, all the average variance extracted (AVE) vary from 0.501 to 0.737 and were greater than the criteria of 0.50 (Fornell \& Larcker, 1981), satisfying adequate convergent validity. Moreover, the result showed that the average variance extracted for any two constructs was always greater than the squared correlation estimate and all correlations between factors each other are significant, supporting the discriminant validity of the scales (Fornell \& Larcker, 1981) (Table 2).

Table 2. Discriminant validity of the measurement model

\begin{tabular}{cccccc}
\hline AVE $/ \mathrm{R}^{2}$ & PQ & BAW & BAS & BL & BE \\
\hline PQ & 0.567 & & & & \\
BAW & 0.057 & 0.501 & & & \\
BAS & 0.204 & 0.102 & 0.525 & & \\
BL & 0.192 & 0.058 & 0.243 & 0.737 & \\
BE & 0.362 & 0.148 & 0.355 & 0.325 & 0,688 \\
\hline
\end{tabular}

\subsection{The Structural Model}

The result from evaluation of the structural model is shown in Figure 2. All of the fit measures indicated that the structural model was acceptable (model fit criteria suggested by Hu \& Bentler, 1999): $(\chi 2) / \mathrm{df}=2.229(\mathrm{p}<0.00)$; $\mathrm{GFI}=0.914 ; \mathrm{AGFI}=0.876 ; \mathrm{CFI}=0.952 ; \mathrm{RMR}=0.057$, and $\mathrm{RMSEA}=0.062$.

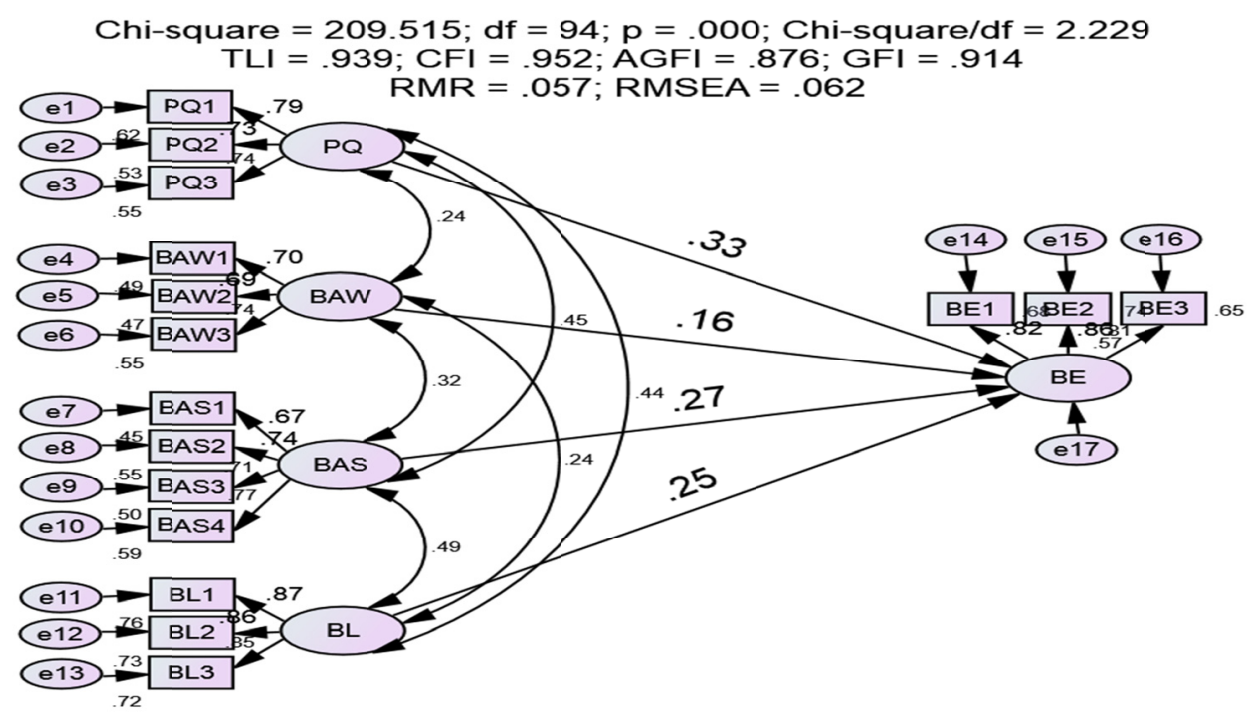

Figure 2. The SEM finalized model and results

With respect to the effect of brand equity dimensions on overall brand equity, the results supported all hypotheses. In other words, H1, H2, H3 and $\mathrm{H} 4$ respectively were accepted, which indicated the positive and significant roles of perceived quality (SEs $=0.331, \mathrm{p}=0.000$ ), brand awareness (SEs $=0.159, \mathrm{p}=0.006$ ), brand association ( $\mathrm{SEs}=0.270, \mathrm{p}=0.000)$ and brand loyalty $(\mathrm{SEs}=0.254, \mathrm{p}=0.000)$ in affecting overall brand equity.

Table 2. Results of hypotheses testing

\begin{tabular}{cccccc}
\hline Relationships & Hypotheses & Standardized Estimate $(\mathrm{SEs})$ & $\mathrm{t}$-value & $\mathrm{p}$-value & Results \\
\hline $\mathrm{BE} \leftarrow \mathrm{PQ}$ & $\mathrm{H} 1$ & 0.331 & 5.079 & 0.000 & Supported \\
$\mathrm{BE} \leftarrow \mathrm{BAW}$ & $\mathrm{H} 2$ & 0.159 & 2.772 & 0.006 & Supported \\
$\mathrm{BE} \leftarrow \mathrm{BAS}$ & $\mathrm{H} 3$ & 0.270 & 3.968 & 0.000 & Supported \\
$\mathrm{BE} \leftarrow \mathrm{BL}$ & $\mathrm{H} 4$ & 0.254 & 4.173 & 0.000 & Supported \\
\hline
\end{tabular}




\section{Conclusion and Implications}

Since its debut in the 1980 's, brand equity has received significant research attention in recent years. Although there are many empirical researches regard the effect of brand equity components on overall brand equity in various contexts, existing research on Heineken in Vietnam is still rare. Vietnamese beer market has been the largest in Southeast Asia, ranking third in Asia and being in the top 25. Among famous beer brands, Heineken is one of the most preferred brands by Vietnamese consumers. Therefore, measuring brand equity of Heineken in the Vietnamese beer market is necessary. Based on theories and empirical results, we propose a researching model and then test hypothesis with 322 consumers. As the results, the model yielded a good overall fit. In terms of hypothesis, the results showed that all hypotheses were supported. The findings of this research suggest some implications.

\subsection{Managerial Implications}

The findings support H1. Perceived quality $(0.331)$ has positive effects on overall brand equity, which is similar with the previous results (e.g. Yoo et al., 2000; Buil et al., 2013b; Saydan, 2013; Ahmad \& Sherwani, 2015; Azadiet al., 2015). The result implicates that in the Vietnamese beer market as the competition between brands are fierce and will be saturated next years, the key factor for Heineken to gain a competitive advantage and develop its brand is to maintain and improve actual quality, which drive perceived quality from consumers. Similarly, H2 showed that brand awareness $(0.159)$ has a positive influence on brand equity. This result is consistent with previous studies by Taleghani \& Almasi (2011); Mohan \& Sequeira, (2012); Ahmad \& Sherwani (2015); Mostafa (2015). The finding points out that Heineken should continue to strengthen brand awareness because the more familiar and more easily identifiable by consumers, the more likely Heineken will be engraved in the consumer's perception. Moreover, the result supports hypothesis H3, which indicated that brand associations (0.270) positively relate to brand equity. This outcome is congruous with conclusion from previous studies (e.g. Tong \& Hawley, 2009; Mohan \& Sequeira, 2012; Ahmad \& Sherwani, 2015). This result implicates that Heineken should maintain unique, creative, distinctive, and impressive brand images because a strong association can create a favorable feeling and behavior toward the brand. Finally, hypothesis $\mathrm{H} 4$ posited that brand loyalty (0.254) enhances overall brand equity. This finding is consistent with various studies (e.g. Yoo et al., 2000; Tong \& Hawley, 2009; Yasin et al., 2012; Buil et al., 2013b; Saydan, 2013; Ahmad \& Sherwani, 2015; Azadi et al., 2015). This result reconfirms Heineken should reinforce customer loyalty because it plays an important role to overall brand equity in the beer market. In summary, the results implicate that marketers should pay attentions to perceived quality, brand awareness, brand association, and brand loyalty, which would enhance overall brand equity. In order to improve components of brand equity as mentioned, Heineken can apply the marketing mix elements such as sales promotions, advertising and distribution intensity etc.

\subsection{Limitations and Future Research}

A number of limitations must be considered. Firstly, the proposed model was tested with the sample size of only 322 consumers. Thus, the results may not be generalizable for Heineken in Vietnamese beer market. Therefore, future research should require a large sample size to reach reliable results. Secondly, this research considers components of brand equity which are the primary drivers of brand equity. Future research should identify the antecedents of brand equity components and it would be interesting to determine which marketing activities (e.g. advertising, sales promotions, distribution intensity) would help increase dimensions of brand equity and overall brand equity.

\section{References}

Aaker, D. A. (1991). Managing brand equity. New York, NY: Free Press.

Ahmad, F., \& Sherwani, N. U. K. (2015). An empirical study on the effect of brand equity of mobile phones on customer satisfaction. International Journal of Marketing Studies, 7(2), 59-69. http://dx.doi.org/10.5539/ ijms.v7n2p59

Azadi, R., Yousefi, B., \& Eydi, H. (2015). The impact of brand country-of-origin image on the formation of brand equity in the sports apparel industry. Universal Journal of Industrial and Business Management, 3(3), 67-73.

Bagozzi, R. P., \& Yi, Y. (1988). On the evaluation of structural equation models. Journal of Academy of Marketing Science, 16(1), 74-94. http://dx.doi.org/10.1007/BF02723327

Berry, L. L. (2000). Cultivating service brand equity. Journal of the Academy of Marketing Science, 28(1), 128-137. http://dx.doi.org/10.1177/0092070300281012 
Bowen, J. T., \& Shoemaker, S. (1998). Loyalty: a strategic commitment. Cornell Hotel and Restaurant Administration Quarterly, 39(1), 12-25. http://dx.doi.org/10.1177/001088049803900104

Buil, I., Chernatony, L., \& Martinez, E. (2013a). Examining the role of advertising and sales promotions in brand equity creation. Journal of Business Research, 66(1), 115-122. http://dx.doi.org/10.1016/j.jbusres.2011.07. 030

Buil, I., Martınez, E., \& Chernatony, L. (2013b). The influence of brand equity on customer responses. Journal of Customer Marketing, 30(1), 62-74. http://dx.doi.org/10.1108/07363761311290849

Chang, H. H., \& Liu, Y. M. (2009). The impact of brand equity on brand preference and purchase intentions in the service industries. The Service Industries Journal, 29(12), 1687-1706. http://dx.doi.org/10.1080/026420 60902793557

Chang, H. H., Hsu, C. H., \& Chung, S. H. (2008). The antecedents and consequences of brand equity in service markets. Asia Pacific Management Review, 13(3), 601-624.

Chaudhuri, A. (1995). Brand equity or double jeopardy? Journal of Product and Brand Management, 4(1), 26-32. http://dx.doi.org/10.1108/10610429510083730

Chen, A. C. H. (2001). Using free association to examine the relationship between the characteristics of brand associations and brand equity. Journal of Product \& Brand Management, 10(7), 439-451.

Chi, H. K., Yeh, H. R., \& Yang, Y. T. (2009). The impact of brand awareness on customer purchase intention: The mediating effect of perceived quality and brand loyalty. The Journal of International Management Studies, 4(1), 135-144.

Farquhar, P. H. (1989). Managing brand equity. Marketing Research, 1, 24-33.

Feldwick, P. (1996). Do we really need "brand equity?". The Journal of Brand Management, 4(1), 9-28. http://dx.doi.org/10.1057/bm.1996.23

Fornell, C., \& Larcker, D. F. (1981). Evaluating structural equation models with unobservable variables and measurement error. Journal of Marketing Research, 18(1), 39-50. http://dx.doi.org/10.2307/3151312

Garvin, D. A. (1983). Quality on the line, Harvard Business Review, 61, 65-73.

Hu, L., \& Bentler, P. M. (1999). Cutoff criteria for fit indexes in covariance structure analysis: Conventional criteria versus new alternatives. Structural Equation Modeling, 6(1), 1-55. http://dx.doi.org/10.1080/10705519909540118

Huong, T. (2016). Cạnh tranh thị truò̀ng bia: Bia Hà Nội và Bia Sài Gòn có dấu hiệu giảm thị phần. Retrieved September 10, 2016, from http://baodautu.vn/canh-tranh-thi-truong-bia-bia-ha-noi-va-bia-sai-gon-co-dauhieu-giam-thi-phan-d38251.html

Jalilvand, M. R., Samiei, N., \& Mahdavinia, S. H. (2011). The effect of brand equity components on purchase intention: An application of Aaker's model in the automobile industry. International Business and Management, 2(2), 149-158.

Keller, K. L. (1993). Conceptualizing, measuring, and managing customer-based brand equity. Journal of Marketing, 57(1), 1-22. http://dx.doi.org/10.2307/1252054

Keller, K. L. (1998). Strategic brand management: building, measuring and managing brand equity. Upper Saddle River NJ: Prentice Hall

Kurniawan, G. I., \& Diryana, I. (2015). Impact on green purchase intention by brand equity dimension. First International Conference on Economics and Banking, 380-386.

Lassar, W., Mittal, B., \& Sharma, A. (1995). Measuring customer-based brand equity. Journal of Customer Marketing, 12(4), 11-19. http://dx.doi.org/10.1108/07363769510095270

Mohan, B. C., \& Sequeira, A. H. (2012). Exploring the interlinkages between brand equity and business performance - towards a conceptual framework. Indian Journal of Marketing, 43(2), 5-10. http://dx.doi.org/10.2139/ssrn.2133940

Mostafa, R. H. A. (2015). The impact of country of origin and country of manufacture of a brand on overall brand equity. International Journal of Marketing Studies, 7(2), 72-83. http://dx.doi.org/10.5539/ijms.v7n2p70

Nhung, T. (2016). Thị truờng bia Việt Nam truớc sụ thèm khát của các nhà đầu tư ngoại. Retrieved September 
10, 2016, from, http://thoibao.today/paper/thi-truong-bia-viet-nam-truoc-su-them-khat-cua-cac-nha-dau-tungoai-999646

Nunnally, J. C., \& Bernstein, I. H. (1994). Psychometric theory (3rd). New York: McGraw-Hill.

Pappu, R., Quester, P. G., \& Cooksey, R. W. (2005). Consumer based brand equity: improving the measurement empirical evidence. Journal of Product and Brand Management, 14(3), 143-154. http://dx.doi.org/10.1108/ 10610420510601012

Phương, T. (2016). Dân ta nhậu đã thành đẳng cấp. Retrieved September 10, 2016, from http://giadinhphapluat.vn/dan-ta-nhau-da-thanh-dang-cap-p34428.html

Rossiter, J. R., \& Percy, L. (1997). Advertising Communication and Promotion Management. New York: McGraw-Hill.

Saydan, R. (2013). Relationship between country of origin image and brand equity: An empirical evidence in England market. International Journal of Business and Social Science, 4(3), 78-88.

Taleghani, M., \& Almasi, M. (2011). Evaluate the factors affecting brand equity from the perspective of customers using Aaker's model. Kuwait Chapter of Arabian Journal of Business and Management Review, $1(4), 64-76$.

Tellis, G. J. (1988). Advertising exposure, loyalty, and brand purchase: A two-stage model of choice. Journal of Marketing Research, 25(2), 134-144. http://dx.doi.org/10.2307/3172645

Tong, X., \& Hawley, J. M. (2009). Measuring customer-based brand equity: Empirical evidence from the sportswear market in China. Journal of Product \& Brand Management, 18(4), 262-271. http://dx.doi.org/10.1108/10610420910972783

Yasin, N. M., Noor, M. N., \& Mohamad, O. (2012). Does image of country-of-origin matter to brand equity?. Journal of Product \& Brand Management, 16(1), 38-48.

Yoo, B., \& Donthu, N. (2001). Developing and validating a multidimensional consumer-based brand equity scale. Journal of Business Research, 52 (1),1-14. http://dx.doi.org/10.1016/S0148-2963(99)00098-3

Yoo, B., Donthu, N., \& Lee, S. (2000). An examination of selected advertising and marketing mix elements and brand equity. Journal of Academic Marketing Science, 28(2), 195-211. http://dx.doi.org/10.1177/009207 0300282002

\section{Copyrights}

Copyright for this article is retained by the author(s), with first publication rights granted to the journal.

This is an open-access article distributed under the terms and conditions of the Creative Commons Attribution license (http://creativecommons.org/licenses/by/4.0/). 